\title{
Epidemiology and Prevention of Hepatitis B
}

\author{
Miriam J. Alter, Ph.D.1
}

\section{ABSTRACT}

The primary goal of hepatitis $B$ prevention programs is reduction of chronic hepatitis $\mathrm{B}$ virus (HBV) infection and $\mathrm{HBV}$-related chronic liver disease. Although donor screening, risk-reduction counseling and services, and effective infection control practices can reduce or eliminate the potential risk for HBV transmission, immunization is by far the single most effective prevention measure. Worldwide, the integration of hepatitis $B$ vaccine into existing childhood vaccination schedules has the greatest likelihood of long-term success. However, by 2000, only 116 of 215 countries had such a policy, representing $31 \%$ of the global birth cohort. In addition, efforts must be strengthened to vaccinate older adolescents and adults with high-risk behaviors or occupations in countries where most $\mathrm{HBV}$ transmission and the morbidity associated with acute hepatitis B occur among persons in these age groups. Although continued immunization of successive birth cohorts should achieve the eventual elimination of HBV transmission, this will not occur for decades without successful vaccination of adults at increased risk for infection.

KEYWORDS: Hepatitis B, epidemiology, prevention

Objectives: After completion of this article, the reader should (1) appreciate the geographic differences in epidemiology of hepatitis $B$, (2) be able to describe the most important routes for transmission of hepatitis B virus in developed and developing countries, and (3) understand the rationale for different hepatitis $B$ vaccination strategies and the need to strengthen immunization programs worldwide.

Accreditation: Tufts University School of Medicine (TUSM) is accredited by the Accreditation Council for Continuing Medical Education to provide continuing medical education for physicians. TUSM takes responsibility for the content, quality, and scientific integrity of this CME activity.

Credit: TUSM designates this educational activity for a maximum of 1.0 hour in Category 1 credit towards the AMA Physicians Recognition Award. Each physician should claim only those hours of credit that he/she actually spent in the educational activity.

Hepatitis B virus $(\mathrm{HBV})$ infection is a major public health problem and cause of infectious disease mortality worldwide. Approximately 2 billion peopleone third of the world's population - have serologic evidence of past or present HBV infection, and 350 million people are chronically infected. Each year over 1 million people die from HBV-related chronic liver disease, including cirrhosis and hepatocellular carcinoma (HCC). ${ }^{1} \mathrm{HCC}$ is one of the most common cancers worldwide, and HBV is responsible for at least $75 \%$ of these cancers. ${ }^{2}$

\section{EPIDEMIOLOGY}

The incubation period of hepatitis B is long, ranging from 45 to 160 days (average 120). HBV is transmitted by percutaneous and mucous membrane exposures to infectious blood and body fluids that contain blood. Al-

Hepatitis B; Editor in Chief, Paul D. Berk, M.D.; Guest Editor, Anna Lok, M.D. Seminars in Liver Disease, volume 23, number 1, 2003. Address for correspondence and reprint requests: Miriam J. Alter, Ph.D., Division of Viral Hepatitis, Centers for Disease Control and Prevention (Mailstop G37), 1600 Clifton Road, Atlanta, GA 30333. E-mail: malter@cdc.gov. ${ }^{1}$ Associate Director for Epidemiologic and Public Health Science, Division of Viral Hepatitis, Centers for Disease Control and Prevention, Atlanta, Georgia. Printed in 2003 by Thieme Medical Publishers, Inc., 333 Seventh Avenue, New York, NY 10001, USA. Tel: +1(212) 584-4662. 0272-8087,p;2003,23,01,039,046,ftx,en;sld00194x. 
though hepatitis B surface antigen ( $\mathrm{HBsAg}$ ) has been detected in a wide variety of body fluids, only serum, semen, and saliva have been demonstrated to be infectious. ${ }^{3,4}$ The presence of hepatitis $\mathrm{B}$ e antigen ( $\mathrm{HBeAg}$ ) in serum correlates with higher titers of HBV (up to $10^{9}$ particles $/ \mathrm{mL}$ ) and greater infectivity. ${ }^{5-7}$ However, HBV strains that have mutations in the precore region of the viral genome that prevents expression of $\mathrm{HBeAg}$ have also been associated with transmission. ${ }^{8}$

Percutaneous exposures that have resulted in HBV transmission include transfusion of blood or blood products, ${ }^{9,10}$ contaminated equipment used for therapeutic injections and other health care-related procedures, ${ }^{11-15}$ illegal injection drug use, ${ }^{16}$ and needle sticks or other injuries from sharp instruments sustained by hospital personnel. ${ }^{5,17}$ In addition, occasional outbreaks of hepatitis $\mathrm{B}$ have been associated with tattooing and acupuncture. ${ }^{18,19}$ Because HBV is stable on environmental surfaces for $\geq 7$ days, ${ }^{20}$ indirect inoculation of $\mathrm{HBV}$ can also occur through inanimate objects.

Transmission of $\mathrm{HBV}$ via transfusion of blood and plasma-derived products has been eliminated in most countries through donor screening for HBsAg and viral inactivation procedures. However, transmission also occurs with inadequately sterilized needles and medical instruments, the reuse of disposable needles and syringes, and contamination of multiple-dose medication vials. Contaminated environmental surfaces have been a major source for HBV transmission among chronic hemodialysis patients. ${ }^{21} \mathrm{HBV}$ transmission among hemodialysis patients is consistently associated with the presence of a chronically infected patient, failure to dialyze that patient in a separate room using dedicated equipment and staff, and failure to vaccinate patients against hepatitis B.

In developing countries, transmission through contaminated injection equipment remains a significant problem because of the difficulty in obtaining disposable needles and syringes and the lack of means for adequately sterilizing reusable equipment. ${ }^{11}$ In developed countries, episodes of HBV transmission from one patient to another in health care settings have also been reported. ${ }^{12-15,22-25}$ In most cases, these transmissions resulted from noncompliance with recommended infection control practices that were designed to prevent crosscontamination of medical equipment and devices.

Although HBV infection was recognized as a frequent occupational hazard among persons who worked in laboratories or were exposed to blood while caring for patients, ${ }^{26,27}$ hepatitis $B$ vaccination of health care workers (and implementation of universal precautions) has made this infection a rare event in this population. ${ }^{28} \mathrm{HBV}$ transmission from infected health care personnel to patients is relatively uncommon but has occurred during invasive surgical, obstetrical, or dental procedures. Most of the reported cases occurred prior to 1991, before hepatitis $B$ vaccination was widely used and before standard (universal) infection control precautions were implemented. These mostly involved infected surgeons or dentists who transmitted during the performance of invasive procedures. ${ }^{29-50}$ However, other health care providers have also been implicated in HBV transmission to patients. ${ }^{44,45,51-53}$ Most of these involved skin conditions in these health care providers (e.g., exudative dermatitis, bleeding lesions or cuts) that contributed to transmission. Substantially fewer episodes of HBV transmission to patients from infected surgeons have been reported worldwide since 1991; most of these were from the United Kingdom. ${ }^{8,54,55}$ All but one of the cases in the United Kingdom involved health care providers who were infected with precore mutations and were negative for $\mathrm{HBeAg}$.

Perinatal and sexual transmission of HBV usually results from mucous membrane exposures to infectious blood or serum-derived body fluids. ${ }^{56,57}$ No infections have been demonstrated in susceptible persons orally exposed to HBsAg-positive saliva, although transmission has been demonstrated to animals by subcutaneous inoculation of saliva. $3,4,56,59$

The risk of perinatal HBV transmission has been well described. This risk is greatest for infants born to women who are $\mathrm{HBeAg}$-positive and ranges from 70 to $90 \%$ at 6 months of age; about $90 \%$ of these children remain chronically infected. ${ }^{60}$ The risk of perinatal infection among infants born to $\mathrm{HBeAg}$-negative mothers ranges from 10 to $40 \%$, with 40 to $70 \%$ of these infected infants remaining chronically infected. ${ }^{56,60}$ Children born to $\mathrm{HBsAg}$-positive mothers who do not become infected during the perinatal period remain at high risk of infection during early childhood ${ }^{61-63}$; in one study, $40 \%$ of infants born to $\mathrm{HBeAg}$-negative mothers became infected by 5 years of age. ${ }^{60}$

Person-to-person spread of HBV can occur in settings involving nonsexual interpersonal contact over a long period of time, such as among household contacts of a chronically infected person. ${ }^{64-67}$ The precise mechanisms of transmission are unknown; however, frequent interpersonal contacts of nonintact skin or mucous membranes with blood-containing secretions or perhaps saliva are the most likely modes of transmission. ${ }^{68}$ Because of the extremely high concentration of virus in the blood, the number of virions in even very small amounts of blood or body fluids can be quite high. In addition, $\mathrm{HBs} \mathrm{Ag}$ contamination of surfaces is widespread in homes of chronically infected persons, ${ }^{68}$ and $\mathrm{HBV}$ remains infectious for long periods of time under ambient conditions.

Among adults, high-risk sexual activity is one of the most frequent routes of transmission for HBV. Historically, men who have sex with men (MSM) were one of the groups at highest risk for HBV infection. Infection in this risk group has been associated with receptive anal intercourse, increased numbers of sexual partners, 
and number of years of sexual activity (70\% of homosexual men were infected after 5 years of sexual activity). ${ }^{57}$ Similar factors have been associated with an increased risk of HBV infection among heterosexual men and women, including number of sexual partners, number of years of sexual activity, and history of other sexually transmitted diseases (STDs)..$^{57}$

Transmission of HBV from persons with acute or chronic hepatitis B to their sexual partners is also an important source of infection. ${ }^{57}$ However, most persons with chronic HBV infection are not aware that they are infected. These silent carriers are the most likely source of infection for persons with multiple sexual partners.

\section{GEOGRAPHIC PATTERNS OFTRANSMISSION}

The endemicity of HBV infection varies greatly worldwide ${ }^{69,70}$ and is influenced primarily by the predominant age at which infection occurs (Table 1). Endemicity of infection is considered high in the parts of the world where at least $8 \%$ of the population is $\mathrm{HBsAg}$ positive. In these areas, 70 to $90 \%$ of the population generally has serological evidence of previous HBV infection. Almost all infections occur during either the perinatal period or early in childhood, which accounts for the high rates of chronic HBV infection in these populations. Risk of HBV infection continues after the first 5 years of life, but its eventual contribution to the high rate of chronic infection is less significant. Chronic infection with $\mathrm{HBV}$ is strongly associated with $\mathrm{HCC}$, and areas with a high endemicity of chronic HBV infection have the highest death rates from this neoplasm.

In areas of the world with an intermediate pattern of $\mathrm{HBV}$ infection, the prevalence of $\mathrm{HBsAg}$ posi- tivity ranges from 1 to $7 \%$ and serological evidence of past infection is found in 10 to $60 \%$ of the population. In these areas there are mixed patterns of infant, early childhood, and adult transmission. Some countries have widely varying infection and transmission rates that reflect the HBV endemicity of the country of origin of immigrant populations. ${ }^{71}$ In most developed parts of the world, the prevalence of chronic HBV infection is less than $1 \%$, and the overall infection rate is 5 to $7 \%$. Within these areas, the highest incidence of acute hepatitis B is among young adults, and high-risk sexual activity and injecting drug use account for most cases of newly acquired hepatitis B. ${ }^{72-75}$ However, even in these low HBV endemic countries, a substantial number of children become infected with HBV, many of whom belong to native populations with high endemic rates of HBV infection or to families of immigrants from high HBV endemic countries. $69,76,77$ Because over $90 \%$ of childhood HBV infections are asymptomatic, the true incidence of childhood disease is not accurately represented by most surveillance data, which reflect reported cases of clinically apparent disease. Although the proportion of infant and early childhood infections is low, they can account for a disproportionately high number of chronic $\mathrm{HBV}$ infections.

\section{PREVENTION}

The primary goal of hepatitis $\mathrm{B}$ prevention programs is reduction of chronic HBV infection and HBV-related chronic liver disease. A secondary goal is the prevention of acute hepatitis B. HBV infection can be prevented by screening blood, plasma, organ, tissue, and semen donors; virus inactivation of plasma-derived products; riskreduction counseling and services; and implementation and maintenance of infection control practices. Although

Table 1 Endemic Patterns of Hepatitis B Virus Infection and Hepatitis B Vaccination Strategies

\begin{tabular}{|c|c|c|c|c|}
\hline $\begin{array}{l}\text { Endemicity } \\
\text { of Infection }\end{array}$ & $\begin{array}{l}\text { Primary Routes } \\
\text { of Transmission }\end{array}$ & $\begin{array}{l}\text { Prevalence of } \\
\text { Chronic Infection } \\
(\%)\end{array}$ & $\begin{array}{l}\text { Percentage of } \\
\text { Global Population } \\
(\%)\end{array}$ & Vaccination Strategy \\
\hline High & $\begin{array}{l}\text { Perinatal } \\
\text { Household } \\
\text { Nosocomial }\end{array}$ & $\geq 8$ & 45 & Routine infant starting at birth \\
\hline Intermediate & $\begin{array}{l}\text { Household } \\
\text { Sexual } \\
\text { Injecting drug use } \\
\text { Occupational } \\
\text { Nosocomial }\end{array}$ & $2-7$ & 43 & $\begin{array}{l}\text { Routine infant } \\
\text { High-risk groups (if resources } \\
\text { available) }\end{array}$ \\
\hline Low & $\begin{array}{l}\text { Sexual } \\
\text { Injecting drug use } \\
\text { Occupational }\end{array}$ & $<2$ & 12 & $\begin{array}{l}\text { Screen pregnant women } \\
\text { Postexposure prophylaxis of } \\
\text { infants born to infected women } \\
\text { Routine infant } \\
\text { Routine adolescent } \\
\text { High-risk groups }\end{array}$ \\
\hline
\end{tabular}


such activities can reduce or eliminate the potential risk for HBV transmission, immunization is by far the single most effective prevention measure.

Preexposure vaccination generally requires three doses to induce an immune response that provides longterm protection. Hepatitis $B$ vaccine can be given along with other commonly used vaccines in a variety of schedules that result in excellent immunogenicity and do not interfere with the immunogenicity of the other vaccines. In addition, infection can be effectively prevented after exposure to $\mathrm{HBV}$ (postexposure prophylaxis) through the passive administration of antibody to $\mathrm{HBsAg}$ (antiHBs) (through hepatitis B immune globulin) and hepatitis $B$ vaccine or with vaccine alone. In areas of high $\mathrm{HBV}$ endemicity, routine vaccination of infants is the only means of interrupting HBV transmission because of the high rates of infant and early childhood infection.

In 1992, the World Health Organization recommended that all countries include hepatitis $B$ vaccine in their routine infant immunization programs. In 2000, only 116 of 215 countries had such a policy, representing $31 \%$ of the global birth cohort. Thus, despite the availability of an effective vaccine for 20 years, most of the world's children remain at risk for HBV infection.

In areas of high HBV endemicity, the timing of the first dose of hepatitis B vaccine is determined by the need for postexposure immunoprophylaxis to prevent perinatal HBV transmission. Where perinatal transmission accounts for a substantial amount of chronic infections, immunization should begin within 12 hours after birth (Table 1). However, in most of these countries it is not feasible to test pregnant women to identify infants who require postexposure immunoprophylaxis. Thus, all infants should receive a dose of vaccine shown to have postexposure efficacy. Where the prevalence of $\mathrm{HBeAg}$ among pregnant women is low and perinatal transmission accounts for a small proportion of chronic HBV infection, the first dose of vaccine can be given soon after birth or can be given when the infant receives the first dose of diphtheria-tetanus-pertussis vaccine.

Ultimately, the design of hepatitis B vaccination programs, including the timing of vaccine doses, is influenced by the epidemiology of HBV infection and patterns of health care (immunization) delivery (Table 1). Thus, prevention of perinatal HBV infection is limited to countries where most infants are born in the hospital or with a birth attendant trained to vaccinate infants.

Immunization strategies in developed countries vary widely. In the United States, the immunization strategy has evolved over time and now includes (1) prevention of perinatal $\mathrm{HBV}$ infection through routine screening of all pregnant women and appropriate postexposure immunoprophylaxis of infants born to $\mathrm{HBsAg-}$ positive women, (2) routine vaccination of infants, (3) routine vaccination of adolescents who have not previously been vaccinated, and (4) vaccination of adults at increased risk of infection. ${ }^{78,79}$ Most countries in Western Europe have focused efforts on prevention of perinatal infection and routine vaccination of adolescents; rarely, routine immunization of infants has also been included. ${ }^{80-83}$ In Eastern European countries, routine immunization of infants has been the primary strategy. $.84,85$

The success of routine immunization of children and adolescents in interrupting HBV transmission has already been demonstrated in areas of high, intermediate, and low HBV endemicity. ${ }^{75,86-88}$ During the 15 years after routine childhood hepatitis B immunization was implemented in Taiwan, the prevalence of chronic HBV infection among children younger than 15 years declined from 10 to $0.7 \%$, a decrease of $93 \%$, and rates of HCC among children 6 to 14 years old declined by $50 \% .{ }^{86,87}$ Similarly, almost a $90 \%$ decline was observed in the overall prevalence of infection (as measured by antibody to hepatitis B core antigen), while prevalence of protective antibody (anti-HBs) remained high. In countries such as Italy and the United States, the incidence of acute hepatitis B has declined dramatically during the past decade, particularly among persons in younger age groups (Fig. 1). ${ }^{75,83,88}$ Furthermore, an estimated 16,000 infections among children have been prevented annually in the United States since routine childhood immunization was implemented. ${ }^{89}$

The integration of vaccine into existing childhood vaccination schedules has the greatest likelihood of successfully lowering the disease incidence. There is already an established infrastructure for vaccine delivery to children, which can ensure high coverage levels, and the hepatitis $B$ vaccine has been shown to provide longterm protection against chronic HBV infection. In addition, routine infant immunization ensures the prevention of HBV infections in subpopulations that have high rates of early childhood infection (e.g., infants and children of immigrant women from high-endemicity areas). The addition of routine adolescent vaccination achieves a more rapid reduction in HBV transmission.

Since the vaccine's availability, hepatitis B immunization efforts have faced several challenges. In the mid-1980s, concern was expressed about the possible risk of human immunodeficiency virus transmission by the original plasma-derived vaccine; however, no transmission of any microbial agent was shown to occur, and the safety of the vaccine was reaffirmed..$^{90,91}$

Although concerns have also been expressed that certain chronic illnesses might be caused by hepatitis B vaccine, no evidence exists that the vaccine causes any of these diseases. ${ }^{92}$ One of the most recent of these involved case reports of multiple sclerosis in adults who received hepatitis B vaccine. However, case-control studies and a report by the Institute of Medicine in the United States found no evidence of a causal relation between hepatitis $B$ vaccination in adults and multiple sclerosis. ${ }^{93-95}$ The vaccine continues to be considered safe by the World 


\section{Italy}

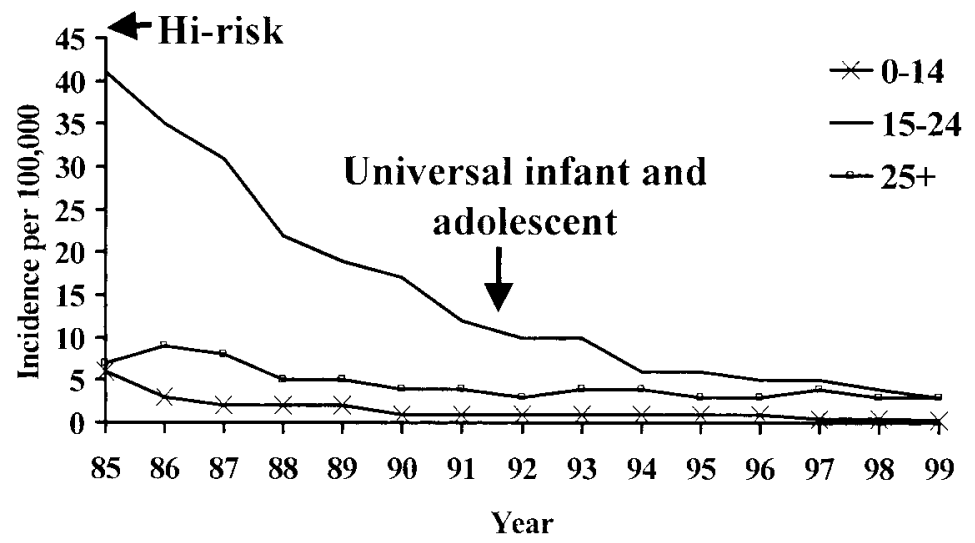

\section{United States}

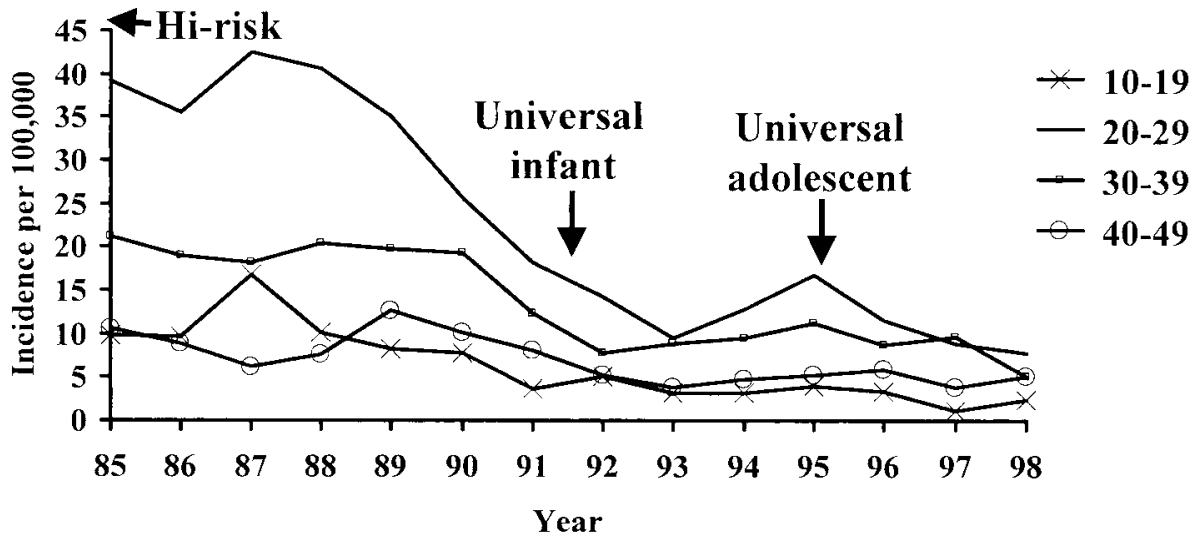

Figure 1 Age-specific incidence of acute hepatitis B in Italy 1985-1999 and the United States 1985-1998 in relation to hepatitis B vaccination strategies. (Adapted from references 73 and 75 .)

Health Organization, the U.S. Food and Drug Administration, and other national and international professional immunization advisory groups.

Variants of HBV with mutations in the amino acids constituting the $a$ determinant have been identified from immunized persons who subsequently became infected with HBV. It has been suggested that these variants may pose a potential threat to the long-term success of hepatitis B vaccination programs. ${ }^{96}$ Early studies using direct sequencing of polymerase chain reaction (PCR) amplicons demonstrated the presence of such mutants in infants who failed immunoprophylaxis to prevent perinatal infection but not in their $\mathrm{HBV}$-infected mothers; one study reported that universal vaccination of children had accelerated the accumulation of these $a$ determinant mutants. ${ }^{97}$ However, a more sensitive method of detection that included sequence-specific, solid-phase detection of amplicons in combination with dilution PCR found that the frequency of these variants among mothers whose infants did not fail postexposure prophylaxis was similar to that of mothers whose infants failed prophylaxis. ${ }^{98}$ Furthermore, experimental studies have demonstrated that currently available hepatitis B vaccines protected chimpanzees against infection by the most common variant (i.e., the variant containing an amino acid substitution at position 145) ${ }^{99}$ However, ongoing surveillance and additional studies will be needed to determine the ultimate significance of these variants.

\section{SUMMARY}

The integration of hepatitis $B$ vaccine into existing infant and childhood vaccination schedules in all countries will eventually eliminate HBV transmission. In developed countries, however, efforts must be strengthened to vaccinate older adolescents and adults with high-risk behaviors or occupations until the cohorts of vaccinated children reach adolescence and adulthood. Most HBV transmission and the morbidity associated with acute hepatitis B occur among older adolescents and young adults, and most of these infections result from sexual transmission. Adults at highest risk for infection are the most difficult to reach with vaccine, and a substantial proportion do not self-identify as belonging to a risk group. There are long-standing recommendations to vaccinate persons who report a history of multiple sex partners, 
treatment for a sexually transmitted disease, MSM, and injecting drug use. For some of these groups (e.g., MSM and drug users), vaccination against both hepatitis $\mathrm{A}$ and hepatitis $\mathrm{B}$ is recommended and combined hepatitis A and hepatitis B vaccine could be used. However, vaccine is rarely offered in settings that provide health care to adults. In the United States, more than half of the reported cases of acute hepatitis B previously received care in STD clinics or correctional settings. ${ }^{75}$ Although continued immunization of successive birth cohorts should achieve the eventual elimination of HBV transmission, this will not occur for decades without successful vaccination of adults at increased risk for infection.

\section{ABBREVIATIONS}

anti-HBs antibody to hepatitis $B$ surface antigen

$\mathrm{HBeAg}$ hepatitis $\mathrm{B}$ e antigen

HBsAg hepatitis B surface antigen

HBV hepatitis B virus

HCC hepatocellular carcinoma

MSM men who have sex with men

PCR polymerase chain reaction

STDs sexually transmitted diseases

\section{REFERENCES}

1. Kane M. Global programme for control of hepatitis B infection. Vaccine 1995;13(Suppl 1):S47-S49

2. Beasley RP. Hepatitis B virus. The major etiology of hepatocellular carcinoma. Cancer 1988;61:1942-1956

3. Alter HJ, Purcell RH, Gerin JL, et al. Transmission of hepatitis B to chimpanzees by hepatitis B surface antigen-positive saliva and semen. Infect Immun 1977;16:928-933

4. Bancroft WH, Snitbhan R, Scott RM, et al. Transmission of hepatitis $\mathrm{B}$ virus to gibbons by exposure to human saliva containing hepatitis B surface antigen. J Infect Dis 1977;135:79-85

5. Alter HJ, Seeff LB, Kaplan PM, et al. Type B hepatitis: the infectivity of blood positive for e antigen and DNA polymerase after accidental needlestick exposure. N Engl J Med 1976;295:909-913

6. Hindman SH, Gravelle CR, Murphy BL, et al. "e" antigen, Dane particles and serum DNA polymerase activity in HBsAg carriers. Ann Intern Med 1976;85:458-460

7. Shikata T, Karasawa T, Abe K, et al. Hepatitis B e antigen and infectivity of hepatitis B virus. J Infect Dis 1977;136:571-576

8. The Incident Investigation Team and Others. Transmission of hepatitis B to patients from four infected surgeons without hepatitis B e antigen. N Engl J Med 1997;336:178-184

9. Alter HJ, Purcell RH, Holland PV, et al. Clinical and serological analysis of transfusion-associated hepatitis. Lancet 1975; 2:838-841

10. Seeff LB, Wright EC, Zimmerman HJ, et al. VA cooperative study of post-transfusion hepatitis and responsible risk factors. Am J Med Sci 1975;270:355-362

11. Hutin YJ, Harpaz R, Drobeniuc J, et al. Injections given in healthcare settings as a major source of acute hepatitis B in Moldova. Int J Epidemiol 1999;28:782-786
12. Alter MJ, Ahtone J, Maynard JE. Multiple-dose vial associated with transmission of hepatitis B virus in a hemodialysis unit. Ann Intern Med 1983;99:330-333

13. Polish LB, Shapiro CN, Bauer F, et al. Nosocomial transmission of hepatitis B virus associated with a spring-loaded fingerstick device. N Engl J Med 1992;326:721-725

14. Hutin YJ, Goldstein ST, Varma JK, et al. An outbreak of hospital-acquired hepatitis B virus infection among patients receiving chronic hemodialysis. Infect Control Hosp Epidemiol 1999;20:731-735

15. Drescher J, Wagner D, Haverich A, et al. Nosocomial hepatitis $\mathrm{B}$ virus infections in cardiac transplant recipients transmitted during transvenous endomyocardial biopsy. J Hosp Infect 1994;26:81-92

16. Lettau L, McCarthy JG, Smith MH, et al. An outbreak of severe hepatitis due to delta and hepatitis B viruses in parenteral drug abusers and their contacts. N Engl J Med 1987;317: $1256-1261$

17. Mast EE, Alter MJ. Prevention of hepatitis B virus infection among health care workers. In: Ellis RS, ed. Hepatitis B Vaccines in Clinical Practice. New York: Marcel Dekker; 1992: 295-307

18. Limentani AE, Elliott LM. An outbreak of hepatitis B from tattooing. Lancet 1979;2:86-88

19. Kent GB, Brondum J, Keenlyside RA, LaFazia LM, Scott HD. A large outbreak of acupuncture-associated hepatitis B. Am J Epidemiol 1988;127:591-598

20. Bond WW, Favero MS, Petersen NJ, et al. Survival of hepatitis $\mathrm{B}$ virus after drying and storage for one week. Lancet 1981;1:550-551

21. Centers for Disease Control and Prevention. Recommendations for preventing transmission of infections among chronic hemodialysis patients. MMWR Recomm Rep 2001; 50(RR-5):1-43

22. Quale JM, Landman D, Wallace B, et al. Déjà vu: nosocomial hepatitis $\mathrm{B}$ virus transmission and fingerstick monitoring. Am J Med 1998;105:296-301

23. Douvin C, Simon D, Zinelabidine H, et al. An outbreak of hepatitis $\mathrm{B}$ in an endocrinology unit traced to a capillaryblood-sampling device. N Engl J Med 1990;322:57-58

24. Vickers J, Painter MJ, Heptonstall J, Yusaf JHM, Craske J. Hepatitis B outbreak in a drug trials unit: investigation and recommendations. Commun Dis Rep 1994;4:R1-R5

25. Oren I, Hershow RC, Ben-Porath E, et al. A common-source outbreak of fulminant hepatitis B in a hospital. Ann Intern Med 1989;110:691-698

26. Dienstag JL, Ryan DM. Occupational exposure to hepatitis B virus in hospital personnel: infection or immunization. Am J Epidemiol 1982;115:26-39

27. Hadler SC, Doto IL, Maynard JE, et al. Occupational risk of hepatitis B infection in hospital workers, Infect Control 1985; 6:24-31

28. Mahoney FJ, Stewart K, Hu H, et al. Progress toward the elimination of hepatitis B virus transmission among health care workers in the United States. Arch Intern Med 1997; 157:2601-2605

29. Carl M, Blakey DL, Francis DP, Maynard JE. Interruption of hepatitis B transmission by modification of a gynaecologist's surgical technique. Lancet 1982;1:731-733

30. Lettau LA, Smith JD, Williams D, et al. Transmission of hepatitis $\mathrm{B}$ with resultant restriction of surgical practice. JAMA 1986;255:934-937

31. Prendergast TJ, Teitelbaum S, Peck B. Transmission of hepatitis B by a surgeon [letter]. West J Med 1991;154:353 
32. Levin ML, Maddrey WC, Wands JR, Mendeloff AI. Hepatitis B transmission by dentists. JAMA 1974;228:1139-1140

33. Goodwin D, Fannin ST, McCracken BB. An oral-surgeon related hepatitis-B outbreak. Calif Morbid 1976;14:1-2

34. Rimland D, Parkin WE, Miller GB, Schrack WD. Hepatitis B outbreak traced to an oral surgeon. N Engl J Med 1977; 296:953-958

35. Hadler SC, Sorley DL, Acree KH, et al. An outbreak of hepatitis B in a dental practice. Ann Intern Med 1981;95:133-138

36. Reingold AL, Kane MA, Murphy BL, et al. Transmission of hepatitis B by an oral surgeon. J Infect Dis 1982;145:262-268

37. Ahtone J, Goodman RA. Hepatitis B and dental personnel: transmission to patients and prevention issues. J Am Dent Assoc 1983;106:219-222

38. Goodman RA, Ahtone JL, Finton RJ. Hepatitis B transmission from dental personnel to patients: unfinished business [editorial]. Ann Intern Med 1983;96:119

39. Shaw FE, Barrett CL, Hamm R, et al. Lethal outbreak of hepatitis B in a dental practice. JAMA 1986;255:3260-3264

40. CDC. Outbreak of hepatitis B associated with an oral surgeon-New Hampshire. MMWR Morb Mortal Wkly Rep 1987;38:132-133

41. Public Health Laboratory Service. Acute hepatitis B associated with gynaecological surgery: a report of a collaborative study by the Communicable Disease Surveillance Centre and the Epidemiological Research Laboratory of the Public Health Laboratory Service together with a district controlof-infection service. Lancet 1980;1:595-596

42. Haerem JW, Siebke JC, Ulstrup J, Geiran O, Helle I. HBsAg transmission from a cardiac surgeon incubating hepatitis $\mathrm{B}$ resulting in chronic antigenemia in four patients. Acta Med Scand 1981;210:389-392

43. District Control of Infection Officer. Acute hepatitis B following gynaecological surgery. J Hosp Infect 1987;9:34-38

44. Coutinho RA, Albrecht-van Lent P, Stoutjesdijk L, et al. Hepatitis B from doctors [letter]. Lancet 1982;1:345-346

45. Polakoff S. Acute hepatitis B in Britain related to previous operations and dental treatment. Br Med J 1986;293:33-36

46. Welch J, Webster M, Tilzey AJ, Noah ND. Hepatitis B infections after gynaecological surgery. Lancet 1989;1:205-207

47. Polakoff S. Acute viral hepatitis B, reported to the Public Health Laboratory Service. J Infect 1990;20:163-168

48. Heptonstall J. Outbreaks of hepatitis B virus infection associated with infected surgical staff. Commun Dis Rep 1991;1: R81-R85

49. Prentice MB, Flower AJE, Morgan GM, et al. Infection with hepatitis B virus after open heart surgery. Br Med J 1992;304: 761-764

50. Johnston BL, MacDonald S, Lee S, et al. Nosocomial hepatitis B associated with orthopedic surgery-Nova Scotia. Can Commun Dis Rep 1992;18:89-90

51. Snydman DR, Hindman SH, Wineland MD, Bryan JA, Maynard JE. Nosocomial viral hepatitis B: a cluster among staff with subsequent transmission to patients. Ann Intern Med 1976;85:573-577

52. Grob PJ, Bischof B, Naeff F. Cluster of hepatitis B transmitted by a physician. Lancet 1981;2:1218-1220

53. Johnson I. Hepatitis B-EEG clinics outbreak investigation: final report, January 1997. Ontario Ministry of Health, Toronto, Canada

54. Harpaz R, Von Seidlin L, Averhoff FM, et al. Transmission of hepatitis $\mathrm{B}$ virus to multiple patients from a surgeon without evidence of inadequate infection control. N Engl J Med 1996;334:549-554
55. Spijkerman IJB, van Doorn L-J, Janssen MHW, et al. Transmission of hepatitis $\mathrm{B}$ virus from a surgeon to his patients during high-risk low-risk surgical procedures during 4 years. Infect Control Hosp Epidemiol 2002;23:306-312

56. Stevens CE, Neurath RA, Beasley RP, et al. HBeAg and anti$\mathrm{HBs}$ detection by radioimmunoassay. Correlation with vertical transmission of hepatitis B virus in Taiwan. J Med Virol 1979;3:237-241

57. Alter MJ, Margolis HS. The emergence of hepatitis B as a sexually transmitted disease. Med Clin North Am 1990;74: 1529-1541

58. Centers for Disease Control. Lack of transmission of hepatitis B to humans after oral exposure to hepatitis B surface antigenpositive saliva. Morbidity and Mortality Weekly Report 1978;27:247-248

59. Glaser JB, Nadler JP. Hepatitis B virus in a cardiopulmonary resuscitation training course. Arch Intern Med 1985;145: $1653-1655$

60. Xu ZY, Liu CB, Francis DP, et al. Prevention of perinatal acquisition of hepatitis $B$ virus carriage using vaccine: preliminary report of a randomized double-blind placebo-controlled and comparative trial. Pediatrics 1985;76:713-718

61. Beasley RP, Hwang L-Y. Postnatal infectivity of hepatitis B surface antigen-carrier mothers. J Infect Dis 1983;147:185-190

62. Franks AL, Berg CJ, Kane MA, et al. Hepatitis B infection among children born in the United States to Southeast Asian refugees. N Engl J Med 1989;321:1301-1305

63. Hurie MB, Mast EE, Davis JP. Horizontal transmission of hepatitis B virus infection to United States-born children of Hmong refugees. Pediatrics 1992;89:269-273

64. Toukan AU, Sharaiha ZK, Abu-el-rub OA, et al. The epidemiology of hepatitis B virus among family members in the Middle East. Am J Epidemiol 1990;132:220-232

65. Pon EW, Ren HX, Margolis HS, et al. Hepatitis B virus infection in Honolulu students. Pediatrics 1993;92:574-578

66. Bernier RH, Sampliner R, Gerety R, et al. Hepatitis B infection in households of chronic carriers of hepatitis $\mathrm{B}$ surface antigen: factors associated with prevalence of infection. Am J Epidemiol 1982;116:199-211

67. Szmuness W, Harley EJ, Prince AM. Intrafamilial spread of asymptomatic hepatitis B. Am J Med Sci 1975;270:293-304

68. Petersen NJ, Barrett DH, Bond WH, et al. Hepatitis B surface antigen in saliva, impetiginous lesions, and the environment in two remote Alaskan villages. Appl Environ Microbiol 1976;32:572-574

69. Margolis HS, Alter MJ, Hadler SC. Hepatitis B: evolving epidemiology and implications for control. Semin Liver Dis 1991;11:84-92

70. Margolis HS, Alter MJ, Hadler SC. Viral hepatitis. In: Evans AS, Kaslow RA, eds. Viral Infections of Humans, 4th ed. New York: Plenum Medical Book; 1997:363-418

71. Bogomolski-Yahalom V, Granot E, Linder N, et al. Prevalence of $\mathrm{HBsAg}$ carriers in native and immigrant pregnant female populations in Israel and passive/active vaccination against HBV of newborns at risk. J Med Virol 1991;34:217-222

72. Germinario C, Lopalco PL, Chicanna M, Da Villa G. From hepatitis B to hepatitis A and B prevention: the Puglia (Italy) experience. Vaccine 2000;18:S83-S85

73. Spada E, Mele A, Ciccozzi M, et al. Changing epidemiology of parenterally transmitted viral hepatitis: results from the hepatitis surveillance system in Italy. Dig Liver Dis 2001;33:778-784

74. Van Steenbergen JE, Niesters HGM, Op de Coul ELM, et al. Molecular epidemiology of hepatitis B virus in Amsterdam 1992-1997. J Med Virol 2002;66:159-165 
75. Goldstein ST, Alter MJ, Williams IT, et al. Incidence and risk factors for acute hepatitis B in the United States, 1982-1998: implications for vaccination programs. J Infect Dis 2002;185: 713-719

76. Connolly JH, McClelland WM, O’Neill HJ, Crowley D. Hepatitis B virus infection in Northern Ireland 1970-1987. Ulster Med J 1989;58:72-82

77. Brabin B, Beeching NJ, Bunn JEG, et al. Hepatitis B prevalence among Somali households in Liverpool. Arch Dis Child 2002;86:67-68

78. Centers for Disease Control. Hepatitis B virus: a comprehensive strategy for eliminating transmission in the United States through universal childhood vaccination: recommendations of the Immunization Practices Advisory Committee (ACIP). Morbidity and Mortality Weekly Report 1991;40(RR-13):1-25

79. Centers for Disease Control and Prevention. Update: recommendations to prevent hepatitis $\mathrm{B}$ virus transmission in the United States. Morbidity and Mortality Weekly Report 1995; 44: 574-575

80. Healy CM, Cafferkey MT, Butler KM, et al. Antenatal hepatitis B screening-is there a need for a national policy? Irish Med J 2001;94:111-112

81. Van Steenbergen JE, Leentvaar-Kuijpers A, Baayen D, et al. Evaluation of the hepatitis B antenatal screening and neonatal immunization program in Amsterdam, 1993-1998. Vaccine 2001;20:7-11

82. Salleras L, Bruguera M, Vidal J, et al. Prevalence of markers in the population of Catalonia (Spain). Rationale for universal vaccination of adolescents. Eur J Epidemiol 1992;8:640644

83. Da Villa G. Rationale for the infant and adolescent vaccination programmes in Italy. Vaccine 2000;18:S31-S34

84. Magdzik W. Hepatitis B epidemiology in Poland, Central and Eastern Europe and the newly independent states. Vaccine 2000;18:S13-S16

85. Popa IM, Pistol A, Mast EE, et al. Use of surveillance for acute hepatitis among children to assess the impact of routine infant hepatitis B vaccination programs in Romania. In: Margolis HS, Alter MJ, Liang TJ, Dienstag JL, eds. Viral Hepatitis and Liver Disease. Atlanta: International Medical Press; 2002:261-262

86. Ni Y-H, Chang M-H, Huang L-M, et al. Hepatitis B virus infection in children and adolescents in a hyperendemic area: 15 years after mass hepatitis B vaccination. Ann Intern Med 2001;135:796-800

87. Chang MH, Chen CJ, Lai MS, et al. Universal hepatitis B vaccination in Taiwan and the incidence of hepatocellular car- cinoma in children. Taiwan Childhood Hepatoma Study Group. N Engl J Med 1997;336:1855-1859

88. Da Villa G, Sepe A, Piccinino F, Scolastico C. Pilot project of universal hepatitis $B$ vaccination of newborns in a hyperendemic area: results after 17 years. In: Margolis HS, Alter MJ, Liang TJ, Dienstag JL, eds. Viral Hepatitis and Liver Disease. Atlanta: International Medical Press; 2002:258-260

89. Armstrong GL, Mast EE, Wojczynski M, Margolis HS. Childhood hepatitis B virus infections in the United States before hepatitis B immunization. Pediatrics 2001;108:11231128

90. Centers for Disease Control. Current trends in hepatitis B virus vaccine safety: report of an inter-agency group. MMWR 1982;31:465-467

91. Centers for Disease Control. Hepatitis B vaccine: evidence confirming lack of AIDS transmission. MMWR 1984;33: 685-687

92. Grotto I, Mandel Y, Ephros M, Ashkenazi I, Shemer J. Major adverse reactions to yeast-derived hepatitis $\mathrm{B}$ vaccines-a review. Vaccine 1998;16:329-324

93. Confavreux C, Suissa S, Saddier P, Bourdès V, Vukusic S. Vaccines in Multiple Sclerosis Study Group. Vaccinations and the risk of relapse in multiple sclerosis. N Engl J Med 2001; 344:319-326

94. Ascherio A, Zhang SM, Hernán MA, et al. Hepatitis B vaccination and the risk of multiple sclerosis. N Engl J Med 2001;344:327-332

95. Institute of Medicine Immunization Safety Review Committee. In: Stratton K, Almario D, McCormick MC, eds. Hepatitis B Vaccine and Demyelinating Disorders, 2002. Washington, DC: National Academy Press; 2002:1-106

96. Francois G, Kew M, Van Damme P, Mphahlele MJ, Meheus A. Mutant hepatitis B viruses: a matter of academic interest only or a problem with far-reaching implications? Vaccine 2001;19:3799-3815

97. Hsu H-Y, Chang M-H, Liaw S-H, Ni Y-H, Chen H-L. Changes of hepatitis B surface antigen variants in carrier children before and after universal vaccination in Taiwan. Hepatology 1999;30:1312-1317

98. Nainan OV, Khristova ML, Byun K-S, et al. Frequency and significance of hepatitis $\mathrm{B}$ virus antibody resistant mutants. Antiviral Ther 2000;5(Suppl):29-30(Abst)

99. Ogata N, Cote PJ, Zanetti AR, et al. Licensed recombinant hepatitis $\mathrm{B}$ vaccine protect chimpanzees against infection with the prototype surface gene mutant of hepatitis B virus. Hepatology 1999;30:779-786 